\title{
Hereditary haemorrhagic telangiectasia and pregnancy: a review of the literature
}

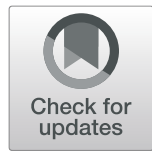

Olivier Dupuis ${ }^{1,2}$, Laura Delagrange ${ }^{3}$ and Sophie Dupuis-Girod ${ }^{3,4^{*}}$ (i)

\begin{abstract}
Background: Hereditary haemorrhagic telangiectasia $(H H T)$ is a dominantly inherited genetic vascular disorder that has prevalence of 1:5000 to 1:8000, and which is characterised by recurrent epistaxis, cutaneous telangiectasia, and arteriovenous malformations (AVMs) that affect many organs including the lungs, gastrointestinal tract, liver, and central nervous system.

The aim here was to carry out a review of the literature on HHT complications during pregnancy in order to guide management decisions.

Main body: A literature review was carried out to analyse all publications on complications that occurred during pregnancy in women with HHT. The PubMed/Medline and Scopus databases were searched. The complications observed in HHT women during pregnancy were then described.

The authors identified 5 case series and 31 case reports that describe the evolution of 1577 pregnancies in 630 women with $\mathrm{HHT}$. The overall maternal death rate described in the case series was estimated at $1.0 \%$ of pregnancies in the case series and 2 maternal deaths occurred in 31 pregnancy case reports. Severe maternal complications occurred in 2.7 to $6.8 \%$ of pregnancies in the case series. Severe complications occurred mostly in the second and third trimester in non-diagnosed and non-screened HHT patients. Severe complications were related to visceral involvement. The most frequent complications were related to pulmonary arteriovenous malformations (PAVMs) (haemothorax $(n=10)$, haemoptysis $(n=4)$, and severe hypoxaemia $(n=3))$. Neurological complications were related to PAVMs in one case (right to left shunt) and to cerebral arteriovenous malformations (CAVM) and intracranial haemorrhage in 2 cases. Complications were related to hepatic arteriovenous malformations (HAVMs) in 8 cases (acutely decompensated heart failure due to hepatic involvement $(n=1)$, dyspnoea related to heart failure $(n=5)$, and hepatobiliary necrosis $(n=2))$.

Conclusion: Based on the literature review, most pregnancies in HHT women occur normally. However, these pregnancies should be considered high-risk, given the potential life-threatening events related to AVM rupture. Furthermore, there is currently no international consensus regarding the medical follow-up of pregnancy in women with $\mathrm{HHT}$ and the aim here was to carry out a review of the literature in order to guide screening and management decisions for this rare disease.

Keywords: Hereditary haemorrhagic telangiectasia, Pregnancy, Arteriovenous malformation, Haemothorax, Haemoptysis, Stroke
\end{abstract}

\footnotetext{
* Correspondence: sophie.dupuis-girod@chu-lyon.fr

${ }^{3}$ Hospices Civils de Lyon, Centre de Référence pour la maladie de

Rendu-Osler, Hôpital Femme-Mère-Enfants, Bron, France

${ }^{4}$ Université Grenoble Alpes, Inserm, CEA, BIG-Biologie du Cancer et de

I'Infection, Grenoble, France

Full list of author information is available at the end of the article
}

(c) The Author(s). 2020 Open Access This article is distributed under the terms of the Creative Commons Attribution 4.0 International License (http://creativecommons.org/licenses/by/4.0/), which permits unrestricted use, distribution, and reproduction in any medium, provided you give appropriate credit to the original author(s) and the source, provide a link to the Creative Commons license, and indicate if changes were made. The Creative Commons Public Domain Dedication waiver (http://creativecommons.org/publicdomain/zero/1.0/) applies to the data made available in this article, unless otherwise stated. 


\section{Introduction}

Hereditary haemorrhagic telangiectasia (HHT) is a dominantly inherited genetic vascular disorder characterised by recurrent epistaxis, cutaneous telangiectasia, and visceral arteriovenous malformations [1]. Clinical diagnosis is based on the Curaçao Criteria defined in 2000 by the Scientific Advisory Board of the HHT Foundation International Inc; these consist of the following 4 signs: 1 . epistaxis that occurs spontaneously on more than 1 occasion; 2. telangiectasias at characteristic sites including the nose, fingers, and oral cavity; 3 . visceral lesions such as pulmonary, hepatic, or cerebral arteriovenous malformations (AVMs); 4. a family history of HHT (first-degree relative diagnosed with $\mathrm{HHT}$ via the same criteria). To be diagnosed with $\mathrm{HHT}$, a patient must meet at least 3 of the 4 criteria [1, 2]. HHT is caused by mutations in ENG (encoding endoglin) [3], ACVRL1 (encoding activin receptorlike kinase 1) [4], or MADH4 (encoding SMAD4), which are responsible for an imbalanced state between anti- and pro-angiogenic factors, such as vascular endothelial growth factor (VEGF) [5]. More than $90 \%$ of all cases of HHT are due to mutations in either ENG or ACVRL1.

Pregnancy, via the associated hormonal changes, promotes modification of the vascular bed and can have an impact on the disease [6]. This corresponds to systemic vasodilatation and a progressive decrease in peripheral vascular resistance until the middle of the second trimester, before beginning to increase late in the third trimester. There is also an increase in cardiac output; the greatest increase, of up to $45 \%$ from baseline, occurs during the first trimester. The increase in cardiac output slows late in the second trimester and drops slightly late in the third trimester [6]. The haemodynamic changes of pregnancy thus exacerbate blood shunting through already abnormal vascular beds [7].

In HHT, complications during pregnancy are rare but can be severe. Screening for pulmonary AVMs is recommended in all cases before pregnancy, as well as pulmonary AVM (PAVM) embolotherapy if possible [8]. However, symptoms may reach clinical thresholds for the first time during pregnancy or after delivery due to PAVMs.

\section{Search strategy}

We performed a literature search using the PubMed/MEDLINE and Scopus databases between March and April 2019 to identify all original articles evaluating or reporting complications during pregnancy in women with HHT. The search strategy was based on a combination of key words and controlled vocabulary for HHT and pregnancy such as "Hereditary Haemorrhagic Telangiectasia" or "OslerWeber-Rendu disease" or "Osler-Weber-Rendu syndrome" and "pregnancy" or "pregnant woman" or pregnancy outcomes". No date or language limits were used.
Studies were excluded if they were not in English or French or if they did not present data about HHT and pregnancy. Articles were double screened by two reviewers (SDG \& LD) based on title and abstract to determine whether they met the inclusion criteria for a full-text review. Articles without abstracts that appeared potentially relevant based on their title were kept for further consideration. Full text screening was completed by all authors.

Data and collection process: data regarding the number of patients and pregnancies, date of events (in gestational week), clinical presentation and treatments, term of delivery, obstetric events, route of delivery, and maternal and foetal outcome were extracted.

\section{Results}

Study selection and characteristics

A total of 104 studies were identified after screening the title and abstract, 50 records were retained and underwent a full text examination, and 34 articles were included in the review (5 case series, 31 case reports; Fig. 1), representing a total of 630 women with HHT and 1577 pregnancies. The characteristics of the 5 case series are summarized in Table 1, and those of the 31 case reports in Table 2.

\section{Case series}

The 5 case series corresponded to a total of 1546 pregnancies in 599 HHT-affected women and 720 live births (unknown information in 2 series) [8-12]. The HHT diagnosis was known before the pregnancy in 4 series [8], and all five studies were retrospective although one study [8] had a prospective component. Severe events occurred in 2.7, 6.1 and $6.8 \%$ of pregnancies as summarized in Table 1 . Two case series reported maternal death during pregnancy $[8,10]$; there was a total of 8 deaths in 645 pregnancies in 246 women (1.2\% of pregnancies and $3.3 \%$ of affected women). PAVM-related complications (hypoxaemia and/or haemorrhage and/or ischaemic stroke) were the most frequent severe event described in HHT women during pregnancy, with a total of 26 events related to PAVM. Furthermore, out of 6 pulmonary haemorrhages published by Shovlin et al. [8], four women had previous PAVM screening and embolisation. Cerebral AVM (CAVM)-related complications (intracranial haemorrhage) were observed in 4 cases and other complications (myocardial infarction, heart failure, deep venous thrombosis) in 7 cases $[8,10,12]$ (Table 1).

\section{Case reports}

A total of 31 case reports of patients with HHT and life threatening events occurring during pregnancies were identified from the literature available. Mean gestational time at the presentation of the adverse events was 27 weeks of pregnancy (range: 20-36). Most complications 


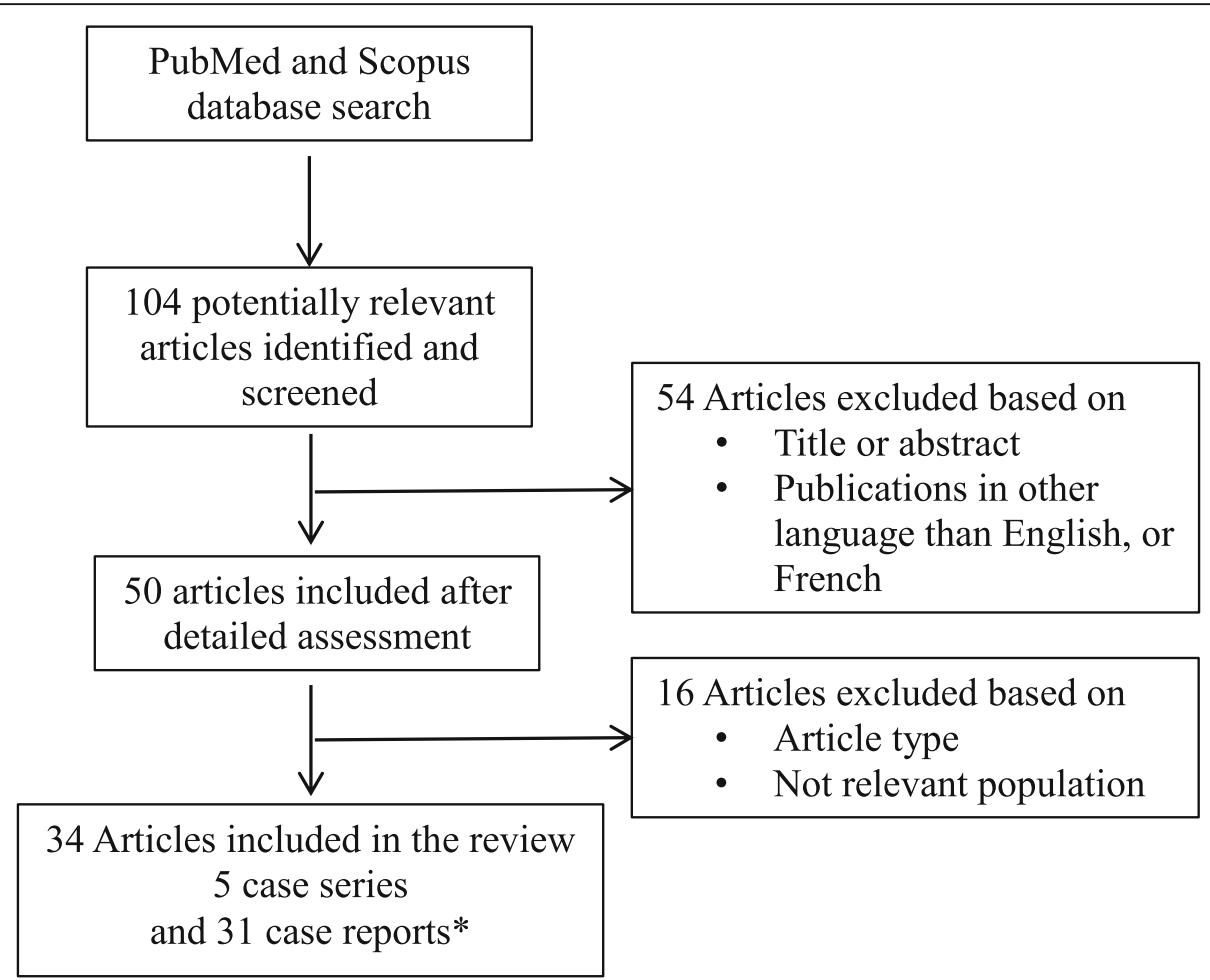

Fig. 1 Study selection flow chart for final inclusion in analysis. ${ }^{*} 2$ case-report in the same article $(n=2)$

appeared at the end of the second trimester or at the beginning of the third trimester of pregnancy.

Two maternal deaths and 2 foetal deaths occurred in 31 pregnancies in this series of case reports [13, 14]. One was due to successive lobar intracerebral haematomas in a 19year old at 30 weeks of gestation, and the second was due to a massive haemorrhage in the intra-peritoneal cavity with multiple AVMs in the gastrointestinal tract.

The most frequent complications were related to PAVMs. Ten women had acute PAVM-related haemothorax [15-24] and of them, 3 had been screened for PAVMs before pregnancy or even been aware of their HHT diagnosis $[18,22,24]$. Haemoptysis during pregnancy occurred in 4 HHT cases [25-28]. Two were weak and both women were able to give birth to live infants at 37 weeks [26, 27]; one woman had been diagnosed and treated for PAVMs 5 years previously. Recanalization of the pulmonary AVM sac, necessary partly because of the pregnancy, occurred with subsequent haemoptysis. Despite successful therapeutic re-embolisation of the afferent pulmonary artery, haemoptysis recurred 5 days later [28]. Three women presented with dyspnoea related to severe hypoxaemia $[18,29$, 30 ] and early-onset foetal growth restriction resulted in foetal death at 25 weeks' gestation in one case [18].

Neurological complications were related to PAVMs in 1 case [31]: this woman with HHT had an ischaemic stroke with hemiparesis in the third trimester of her pregnancy while she was being treated for PAVMs. The patient developed severe pulmonary insufficiency with post-partum haemothorax [31]. The complications were related to CAVMs and intracranial haemorrhage in 2 cases [13, 32], resulting in one foetal death.

Complications were related to hepatic AVMs (HAVMs) in 8 case reports [33-39]. There were 6 cases of acute decompensation heart failure due to hepatic involvement during pregnancy. In one case, a pregnant woman with previously unknown HHT was admitted for pre-term labour and cardiac failure. After a caesarean section, congestive signs improved with medical treatment [36]. In other cases of HHT undiagnosed during pregnancy, congestive heart failure improved spontaneously after delivery $[34,35,37]$. Three women underwent a post-partum liver transplant. In 1 case, the pregnant woman with known HHT had severe cholangitis and progressive liver dysfunction; delivery was induced in order to allow the liver transplant to be performed [40]. In 2 other cases, the women had hepatobiliary necrosis diagnosed on the basis of acute abdominal pain [38, 39]. One woman had digestive bleeding from a perforated gastric ulcer that could not be controlled endoscopically [14]. Branch retinal artery occlusion was observed in one case [41].

\section{Discussion}

In the context of pregnancy, severe complications can occur in HHT women, and this literature review indicates that HHT pregnancies are likely to present significant 


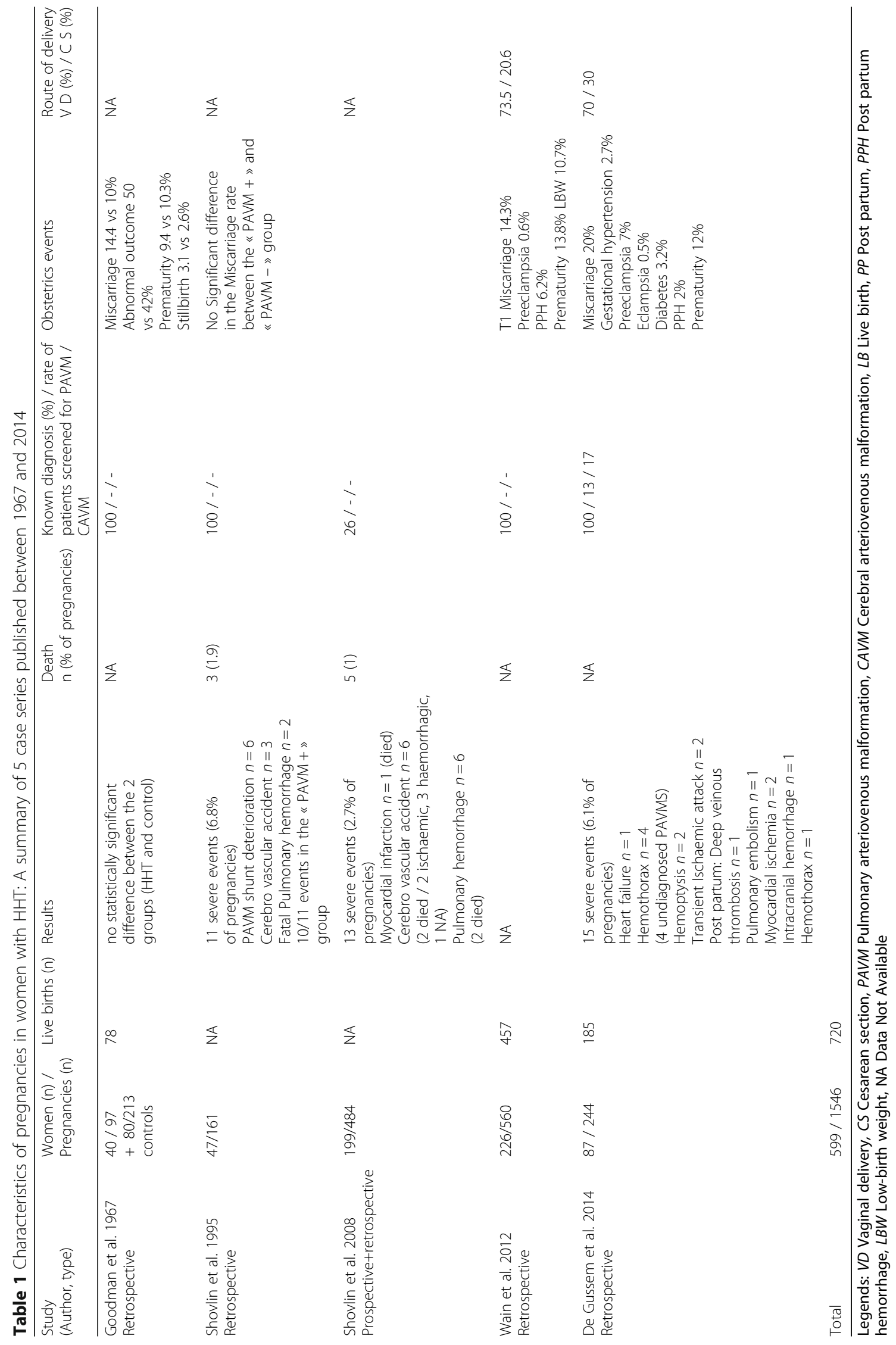


Table 2 Severe complications occurring during pregnancy or post-partum in women with HHT and published as case report $(n=$ 31)

\begin{tabular}{|c|c|c|c|c|c|c|c|}
\hline Complication & Study & $\begin{array}{l}\text { Treatment } \\
\text { T: Transfusion } \\
\text { S: Surgery } \\
\text { E: Embolisation } \\
\text { D: Drain }\end{array}$ & $\begin{array}{l}\text { Date of } \\
\text { events (wg) }\end{array}$ & $\begin{array}{l}\text { Clinical } \\
\text { presentation }\end{array}$ & $\begin{array}{l}\text { Term of } \\
\text { delivey (wg) }\end{array}$ & Maternal outcome & $\begin{array}{l}\text { Fœtal } \\
\text { outcome }\end{array}$ \\
\hline \multirow[t]{10}{*}{ Haemothorax } & $\begin{array}{l}\text { Texier et al. } \\
2018\end{array}$ & $\mathrm{~T}+\mathrm{S} / \mathrm{HHT}-$ & 26 & Chest pain & 40 & Good & Live infant \\
\hline & $\begin{array}{l}\text { Md Noh } \\
\text { et al. } 2018\end{array}$ & E/HHT- & 20 & Dyspnea & 20 & Small bowel active hemorrhage & Foetal death \\
\hline & $\begin{array}{l}\text { Raiya et al. } \\
2017\end{array}$ & $\mathrm{D}+\mathrm{E} / \mathrm{HHT}-$ & 23 & $\begin{array}{l}\text { Dyspnea, chest } \\
\text { pain }\end{array}$ & 40 & Good & Live infant \\
\hline & $\begin{array}{l}\text { Jakobi et al. } \\
2001\end{array}$ & $\mathrm{~S} / \mathrm{HHT}+$ & 26 & $\begin{array}{l}\text { Severe } \\
\text { hypoxemia }\end{array}$ & 40 & Hypoxemia PP embolisation & SGA infant \\
\hline & $\begin{array}{l}\text { Adegboyega } \\
\text { et al. } 1996\end{array}$ & D/HHT- & 29 & $\begin{array}{l}\text { Dyspnea Chest } \\
\text { pain }\end{array}$ & 40 & Discharged no sequelae & $\begin{array}{l}\text { Live infant } \\
\text { (CS) }\end{array}$ \\
\hline & $\begin{array}{l}\text { Freixinet } \\
\text { et al. } 1995\end{array}$ & $\mathrm{D}+\mathrm{S} / \mathrm{HHT} ?$ & 27 & Dyspnea & $?$ & Severe mitral regurgitation & Live infant \\
\hline & $\begin{array}{l}\text { Bevelaqua } \\
\text { et al. } 1992\end{array}$ & $\mathrm{D}+\mathrm{E} / \mathrm{HHT}-$ & 26 & $\begin{array}{l}\text { Dyspnea Chest } \\
\text { pain }\end{array}$ & 40 & Diagnosed 6 wk & Live infant \\
\hline & $\begin{array}{l}\text { Laroche et al. } \\
1992\end{array}$ & $\mathrm{D}+\mathrm{S} / \mathrm{HHT}+$ & 29 & $\begin{array}{l}\text { Dyspnea Chest } \\
\text { pain }\end{array}$ & 37 & Post embolotherapy & Live infant \\
\hline & $\begin{array}{l}\text { Gammon } \\
\text { et al. } 1990\end{array}$ & $\mathrm{D}+\mathrm{E} / \mathrm{HHT}-$ & 24 & $\begin{array}{l}\text { Dyspnea Chest } \\
\text { pain }\end{array}$ & 30 & Heart failure resolved & Live infant \\
\hline & $\begin{array}{l}\text { Waring et al. } \\
1990\end{array}$ & $\mathrm{D}+\mathrm{E} / \mathrm{HHT}+$ & 26 & Dyspnea & 32 & Heart failure resolved & Live infant \\
\hline \multirow[t]{4}{*}{ Hemoptysis } & $\begin{array}{l}\text { Banerjee } \\
\text { et al. } 2018\end{array}$ & & 34 & Hemoptysis & - & Good & - \\
\hline & $\begin{array}{l}\text { Tandon et al. } \\
2017\end{array}$ & reE of PAVM/HHT+ & 32 & $\begin{array}{l}\text { Unconscious } \\
\text { and hypoxia }\end{array}$ & 37 & Good & $\begin{array}{l}\text { Live infant } \\
\text { (VD) }\end{array}$ \\
\hline & $\begin{array}{l}\text { Yaniv-Salem } \\
\text { et al. } 2017\end{array}$ & reE of PAVM/HHT+ & 35 & $\begin{array}{l}\text { Massive } \\
\text { hemoptysis }\end{array}$ & 37 & Good & $\begin{array}{l}\text { Live infant } \\
\text { (VD) }\end{array}$ \\
\hline & $\begin{array}{l}\text { Wispelaere } \\
\text { et al. } 1996\end{array}$ & $-/ \mathrm{HHT}+$ & 10 & $\begin{array}{l}\text { Hemoptysis, } \\
\text { transient loss } \\
\text { of consciousness } \\
\text { and tachycardia }\end{array}$ & $\begin{array}{l}\text { Therapeutic } \\
\text { abortion }\end{array}$ & $\begin{array}{l}\text { Well, required resection } \\
\text { of PAVM }\end{array}$ & - \\
\hline \multirow[t]{3}{*}{$\begin{array}{l}\text { Severe } \\
\text { Hypoxemia }\end{array}$} & $\begin{array}{l}\text { Worda et al. } \\
2007\end{array}$ & $-/ \mathrm{HHT}+$ & 12 & $\begin{array}{l}\text { Dyspnea, } \\
\text { cyanosis }\end{array}$ & 32 & Clinically improved & $\begin{array}{l}\text { Live infant } \\
\text { (CS) }\end{array}$ \\
\hline & $\begin{array}{l}\text { Jakobi et al. } \\
2001\end{array}$ & $-/ \mathrm{HHT}+$ & 25 & Hypoxemia IUGR & 25 & - & Foetal death \\
\hline & $\begin{array}{l}\text { Swinburne } \\
\text { et al. } 1986\end{array}$ & $-/ \mathrm{HHT}+$ & 35 & $\begin{array}{l}\text { Dyspnea, } \\
\text { cyanosis }\end{array}$ & 35 & $\begin{array}{l}\text { Post partum PAVM } \\
\text { surgery } \\
\text { Active limited live }\end{array}$ & $\begin{array}{l}\text { Live infant } \\
\text { (CS) }\end{array}$ \\
\hline $\begin{array}{l}\text { Cerebral } \\
\text { Ischemic stroke }\end{array}$ & $\begin{array}{l}\text { Swietlik et al. } \\
2008\end{array}$ & Craniotom/HHT+ & 35 & $\begin{array}{l}\text { Headache and } \\
\text { dyspnea } \\
\text { Brain abscess + } \\
\text { PAVM }\end{array}$ & 35 & $\begin{array}{l}\text { Post partum Hemothorax } \\
\text { requiring } \\
\text { re Embolisation }\end{array}$ & $\begin{array}{l}\text { Live infant } \\
\text { (CS) }\end{array}$ \\
\hline \multirow[t]{2}{*}{$\begin{array}{l}\text { Intracranial } \\
\text { hemorrhage }\end{array}$} & $\begin{array}{l}\text { Gillard et al. } \\
1996\end{array}$ & $\begin{array}{l}\text { CAVM surgery/ } \\
\text { HHT- }\end{array}$ & 21 & $\begin{array}{l}\text { Right } \\
\text { hemiplegia, } \\
\text { aphasia }\end{array}$ & 38.5 & $\begin{array}{l}\text { Post partum epilepsy, Right } \\
\text { hemiparesis }\end{array}$ & $\begin{array}{l}\text { Live infant } \\
\text { (CS) }\end{array}$ \\
\hline & $\begin{array}{l}\text { Neau et al. } \\
1988\end{array}$ & $\begin{array}{l}\text { Brain surgery/ } \\
\text { HHT- }\end{array}$ & 30 & $\begin{array}{l}\text { Right hemiplegia } \\
\text { with aphasia } \\
\text { violent headache } \\
\text { and vomiting }\end{array}$ & 30 & $\begin{array}{l}\text { Fatal (multiple CAVM, } 5 \\
\text { hematomas) }\end{array}$ & $\begin{array}{l}\text { Foetal death } \\
\text { (VD) }\end{array}$ \\
\hline $\begin{array}{l}\text { Pulmonary } \\
\text { edema }\end{array}$ & $\begin{array}{l}\text { Euser et al. } \\
2012\end{array}$ & $\mathrm{HHT}+$ & 33 & $\begin{array}{l}\text { Pre-eclampsia, } \\
\text { extensive edema } \\
\text { in her legs and } \\
\text { face }\end{array}$ & 34 & Good & $\begin{array}{l}\text { Live infant } \\
\text { (CS) }\end{array}$ \\
\hline
\end{tabular}


Table 2 Severe complications occurring during pregnancy or post-partum in women with HHT and published as case report $(n=$ 31) (Continued)

\begin{tabular}{|c|c|c|c|c|c|c|c|}
\hline Complication & Study & $\begin{array}{l}\text { Treatment } \\
\text { T: Transfusion } \\
\text { S: Surgery } \\
\text { E: Embolisation } \\
\text { D: Drain }\end{array}$ & $\begin{array}{l}\text { Date of } \\
\text { events (wg) }\end{array}$ & $\begin{array}{l}\text { Clinical } \\
\text { presentation }\end{array}$ & $\begin{array}{l}\text { Term of } \\
\text { delivey (wg) }\end{array}$ & Maternal outcome & $\begin{array}{l}\text { Fœtal } \\
\text { outcome }\end{array}$ \\
\hline \multirow{5}{*}{$\begin{array}{l}\text { High output } \\
\text { heart failure all } \\
\text { related to liver } \\
\text { AVM }\end{array}$} & $\begin{array}{l}\text { Berthelot } \\
\text { et al. } 2015\end{array}$ & Diuretics/HHT- & 25 & Dyspnea & 33 & $\begin{array}{l}\text { At day } 16 \text { post partum complete } \\
\text { regression of congestive signs }\end{array}$ & $\begin{array}{l}\text { Live infant } \\
\text { (CS) }\end{array}$ \\
\hline & $\begin{array}{l}\text { Lai et al. } \\
2010\end{array}$ & $? / \mathrm{HHT+}$ & 36 & Rest Dyspnea & 36 & Good & $\begin{array}{l}\text { Live infant } \\
\text { (CS) }\end{array}$ \\
\hline & $\begin{array}{l}\text { Goussous } \\
\text { et al. } 2009\end{array}$ & ?/HHT- & 29 & $\begin{array}{l}\text { Right sided heart } \\
\text { failure and } \\
\text { preterm labor }\end{array}$ & & $\begin{array}{l}\text { On post partum day 2: dyspnea } \\
\text { and lower extremity edema }\end{array}$ & $?(\mathrm{CS})$ \\
\hline & $\begin{array}{l}\text { Livneh et al. } \\
1988\end{array}$ & Diuretics/HHT+ & 26 & $\begin{array}{l}\text { Weakness, } \\
\text { dyspnea }\end{array}$ & 35 (?) & At 4 months Post partum Good & Live infant \\
\hline & $\begin{array}{l}\text { Livneh et al. } \\
1988\end{array}$ & Diuretics/HHT- & 26 & Dyspnea & 40 & $\begin{array}{l}\text { At } 4 \text { months Post partum no } \\
\text { more heart failure }\end{array}$ & Live infant \\
\hline \multirow[t]{2}{*}{ Hepatobiliary } & $\begin{array}{l}\text { Mclnroy } \\
\text { et al. } 1998\end{array}$ & $\begin{array}{l}\text { Post partum Liver } \\
\text { transplantation } \\
\text { HHT+ }\end{array}$ & 30 & $\begin{array}{l}\text { Abdominal pain } \\
+ \text { fever }\end{array}$ & 30 & $\begin{array}{l}\text { Biliary necrosis, liver transplant } \\
\text { postpartum }\end{array}$ & Live infant \\
\hline & $\begin{array}{l}\text { Bauer et al. } \\
1995\end{array}$ & $\begin{array}{l}\text { Liver transplant } \\
\text { HHT- }\end{array}$ & - & $\begin{array}{l}\text { Abdominal pain } \\
\text { dyspnea, } \\
\text { Melaena }\end{array}$ & - & Liver transplant & - \\
\hline $\begin{array}{l}\text { Gastrointestinal } \\
\text { bleeding }\end{array}$ & $\begin{array}{l}\text { Hillert et al. } \\
2001\end{array}$ & $\begin{array}{l}\text { Liver } \\
\text { transplantation/ } \\
\text { HHT+ }\end{array}$ & 27 & $\begin{array}{l}\text { Diffuse } \\
\text { abdominal pain } \\
\text { cholangitis }\end{array}$ & 29 & Good & $\begin{array}{l}\text { Live infant } \\
\text { (CS) }\end{array}$ \\
\hline $\begin{array}{l}\text { Branch retinal } \\
\text { artery occlusion }\end{array}$ & $\begin{array}{l}\text { Askim et al. } \\
2017\end{array}$ & $\begin{array}{l}\text { Subcutaneous } \\
\text { Heparin + } \\
\text { PAVM } \\
\text { embolization/ } \\
\text { HHT- }\end{array}$ & 12 & $\begin{array}{l}\text { Sudden painless } \\
\text { scotoma in left } \\
\text { eye }\end{array}$ & 40 & Good & $\begin{array}{l}\text { Live infant } \\
\text { (VD) }\end{array}$ \\
\hline $\begin{array}{l}\text { Massive } \\
\text { intraperitoneal } \\
\text { haemorrhage }\end{array}$ & $\begin{array}{l}\text { Sivarani et al. } \\
2010\end{array}$ & HHT+ & 36 & $\begin{array}{l}\text { High-output } \\
\text { cardiac failure }\end{array}$ & 36 & $\begin{array}{l}\text { Fatal (on post-partum: massive } \\
\text { haemorrhage in the intra- } \\
\text { peritoneal cavity with multiple } \\
\text { AVMs in the gastrointestinal tract) }\end{array}$ & $\begin{array}{l}\text { Live infant } \\
\text { (CS) }\end{array}$ \\
\hline
\end{tabular}

Legends: HHT- means that the diagnosis was not done before the complication and HHT+ means that the diagnosis was known before the complication. CS Cesarean section, PAVM Pulmonary arteriovenous malformation, SGA Small for gestational age, VD Vaginal delivery

maternal and/or foetal risks. One large study reported that the overall maternal death rate was $1.0 \%$ of pregnancies (95\% confidence interval $[0.1 ; 1.9])[8]$ based on analysis of retrospective and prospective data and on data from the "relatives group", defined as non-HHT women's first degree relatives. Interestingly, all deaths occurred in women not under medical supervision for HHT. Furthermore, 2 case reports indicated a fatal maternal outcome in 2 cases $[13,14]$. This maternal death rate is probably underestimated in cases of women undiagnosed before pregnancy. Severe maternal complications occurred in 2.7 to $6.8 \%$ of pregnancies $[8,10,12]$ in the case series and 31 case reports published from 1986 to 2018. This indicates that, in women known to have HHT, and even if the majority of HHT pregnancies are uneventful, specific high-risk pregnancy monitoring is needed. Foetal death is very rare: among the case reports, 3 foetal deaths were reported [13, $16,18]$, secondary to maternal complications, severe hypoxaemia with early-onset growth retardation at 25 weeks' gestation in one case and maternal intracranial haemorrhage in the other case, with maternal death.

Pregnancy has a dramatic effect on the cardiovascular system and many complications in the HHT pregnancies occurred in the second and third trimesters at the time when peripheral resistance is reduced (by $35-40 \%$ ), as is systemic vascular resistance [42]. Furthermore, given the physiological demands of utero-placental circulation and the developing foetus, there is an increase in cardiac output, with the biggest increase of up to $45 \%$ from baseline occurring during the first trimester. The increase in cardiac output slows late in the second trimester and drops slightly, late in the third trimester. We hypothesized that the complications in HHT patients during pregnancy related to pulmonary, liver and cerebral AVMs are favoured by these vascular changes in an abnormal vascular bed. Moreover, it has been shown by Rizvi et al. that, in patients with pulmonary AVMs - a chronic adapted state - evaluating arterial oxygenation can be falsely reassuring during 
pregnancy and haemoglobin is a vital determinant of arterial oxygen content that needs to be evaluated [43].

Screening and treatment of PAVMs before pregnancy is a priority because these are present in 25 to $50 \%$ of HHT women and can lead to haemothorax, which was the most frequent complication in the published case series and case reports. Incidence of haemothorax in 2 studies was $2.1 \%(4 / 185)$ (95\% confidence interval $0.7-$ $5.6 \%)$ [12], and $1.4 \%(6 / 484)$ (95\% confidence interval $0.2-2.5 \%$ ) [8] per pregnancy. However, as reported by Shovlin et al. [8], there was significant improvement in survival in women in whom the diagnosis of HHT or PAVMs had been made before pregnancy; all women in whom the diagnosis had been made previously, and who presented with haemothorax, survived. On the other hand, PAVM bleeds could be observed even in women who had been previously treated with embolotherapy before the pregnancy. Other complications related to PAVMs include haemoptysis, severe hypoxaemia, paradoxical emboli with brain abscess, paradoxical emboli with ischaemic cerebral stroke, paradoxical emboli with ocular ischaemia. Most complications from PAVMs occurred during the second or third trimester, which seems to be related to high cardiac output. In treated or untreated patients, specific clinical monitoring should be proposed, including regular measuring of oxygen saturation, and all patients should be informed of the risk of coughing up blood, which is not a nosebleed, and it should justify an immediate specialised consultation to exclude a PAVM rupture $[8,12]$.

Complications related to HAVMs were described in 8 case reports but were rare in case series. We can hypothesize that this difference is related to recruitment bias. The largest series published were from HHT expert centres specialised in pulmonology and internal medicine and not from hepato-gastroenterology or cardiology $[8,11,12]$. The most common complication of HAVMs in patients with HHT leads to high-output cardiac failure (6 cases [12, 34-37]), followed by hepatobiliary necrosis leading to liver transplant in 2 cases [38, 39]. Severe liver involvement in HHT is rare in young patients and usually clinically diagnosed through dyspnoea in women after the age of 50 years [44]. For this reason, complications are rare between 20 and 40 years of age even if cardiac output is higher during pregnancy, but easy to screen by liver Doppler ultrasound [45].

The risk of complications from cerebral or spinal AVMs was very low in the case series (4 intracranial haemorrhages $[8,12]$, no spinal haemorrhage) and case reports (2 intracranial haemorrhages $[13,32]$, no spinal haemorrhage). During pregnancy, spontaneous intracranial haemorrhage in all women occurs at a rate of 0.9 to 7.5 per 100,000 deliveries [46], which is higher than non-pregnant age-matched women. Even if CAVMs are frequent in asymptomatic HHT patients (15-25\%) [47], it has been suggested that the risk of intracranial brain haemorrhage in HHT patients was lower than in sporadic CAVM patients [48]. This is not true for the risk of rebleeding, with a higher risk of re-rupture [49]. Screening for CAVMs is highly debated among HHT experts. The most recent HHT guidelines were drawn up in 2006 and concluded that there is no evidence for guiding the management of CAVMs during pregnancy and delivery [50]. The bleeding risk with CAVMs in HHT has been estimated retrospectively at $0.5 \%$ per year [48], but there are several cases of dramatic haemorrhage. Furthermore, even if the treatment can reduce risks, the prevention procedures have their own complication rate, and treatment techniques have treatment-associated morbidity and mortality [51, 52]. This was highlighted by the ARUBA trial (A Randomized Trial of Unruptured Brain Arteriovenous Malformations) that found that medical management alone was more effective than interventional therapy $[51,53]$. We did not find any report of spinal AVM bleeding during pregnancy or more particularly at birth after epidural anaesthesia, even if it is a potential risk. Spinal AVMs are rare and have mostly been reported in children [54].

Finally, HHT can affect pregnancies with intra-uterine growth retardation and intra-uterine foetal death via chronic hypoxaemia, maternal hypovolaemia or maternal death. However, in the published series, miscarriage was observed in 14.4 to $20 \%$ during the first trimester [9, 11 , $12]$, and prematurity in $9.4,13.8$ and $12 \%[9,11,12]$. These figures were not significantly different from those of the control group, nor those found in the general population.

\section{Conclusion}

Improving HHT diagnosis and information via reference centres and general information is an objective, and women should be educated about screening and possible pregnancy-related risks before becoming pregnant. In all cases, even if severe complications are rare, HHT pregnancies are high-risk and need reinforced monitoring from a maternal as well as a foetal point of view.

\footnotetext{
Abbreviations

ACVRL1 = ALK1: Activin receptor-like kinase 1; ARUBA: A Randomized trial of Unruptured Brain Arteriovenous malformations; AVM(s): Arteriovenous malformation(s); CAVM: Cerebral arteriovenous malformation; ENG: Endoglin; HAVM: Hepatic arteriovenous malformation; HHT: Hereditary haemorrhagic telangiectasia; MADH4: Mothers against decapentaplegic homolog 4; PAVM: Pulmonary arteriovenous malformation; VEGF: Vascular endothelial growth factor
}

Acknowledgements

The authors would like to express their gratitude to the HHT Working Group of the European Reference Network for Rare Vascular Diseases (VASCERN) for their helpful discussion. 


\section{Authors' contributions}

OD contributed as a first author and obstetrician by creating the study design, reviewing the literature and the manuscript. LD contributed as a coauthor by reading and summarising articles, reviewing and substantively revised the manuscript. SD-G contributed as the last author and HHT expert by creating the study design, reading and summarising articles, writing the manuscript. All authors read and approved the final manuscript.

\section{Funding}

The French National HHT Reference Centre (www.rendu-osler.fr) is supported by the French Ministry of Health and the Hospices Civils de Lyon.

\section{Availability of data and materials}

The datasets used and/or analysed during the current study are available from the corresponding author on request.

\section{Ethics approval and consent to participate}

Not applicable.

\section{Consent for publication}

Not applicable.

\section{Competing interests}

The authors declare that they have no competing interests.

\section{Author details}

${ }^{1}$ Hospices Civils de Lyon, Service de Gynécologie-Obstétrique, Hôpital

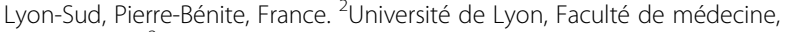
Lyon, France. ${ }^{3}$ Hospices Civils de Lyon, Centre de Référence pour la maladie de Rendu-Osler, Hôpital Femme-Mère-Enfants, Bron, France. ${ }^{4}$ Université Grenoble Alpes, Inserm, CEA, BIG-Biologie du Cancer et de I'Infection, Grenoble, France.

\section{Received: 16 October 2019 Accepted: 20 December 2019}

Published online: 07 January 2020

\section{References}

1. Shovlin CL, Guttmacher AE, Buscarini E, Faughnan ME, Hyland RH, Westermann $\mathrm{CJ}$, et al. Diagnostic criteria for hereditary hemorrhagic telangiectasia (RenduOsler-weber syndrome). Am J Med Genet. 2000;91(1):66-7.

2. Shovlin CL, Buscarini E, Kjeldsen AD, Mager HJ, Sabba C, Droege F, et al. European reference network for rare vascular diseases (VASCERN) outcome measures for hereditary Haemorrhagic telangiectasia (HHT). Orphanet J Rare Dis. 2018;13(1):136 Epub 2018/08/17.

3. McAllister KA, Grogg KM, Johnson DW, Gallione CJ, Baldwin MA, Jackson CE, et al. Endoglin, a TGF-beta binding protein of endothelial cells, is the gene for hereditary haemorrhagic telangiectasia type 1. Nat Genet. 1994;8(4):345-51.

4. Johnson DW, Berg JN, Baldwin MA, Gallione CJ, Marondel I, Yoon SJ, et al. Mutations in the activin receptor-like kinase 1 gene in hereditary haemorrhagic telangiectasia type 2. Nat Genet. 1996;13(2):189-95.

5. David L, Mallet C, Mazerbourg S, Feige JJ, Bailly S. Identification of BMP9 and BMP10 as functional activators of the orphan activin receptor-like kinase 1 (ALK1) in endothelial cells. Blood. 2007;109(5):1953-61.

6. Meah VL, Cockcroft JR, Backx K, Shave R, Stohr EJ. Cardiac output and related haemodynamics during pregnancy: a series of meta-analyses. Heart. 2016;102(7):518-26 Epub 2016/01/23.

7. Yeomans ER, Gilstrap LC 3rd. Physiologic changes in pregnancy and their impact on critical care. Crit Care Med. 2005;33(10 Suppl):S256-8 Epub 2005/ $10 / 11$.

8. Shovlin CL, Sodhi V, McCarthy A, Lasjaunias P, Jackson JE, Sheppard MN. Estimates of maternal risks of pregnancy for women with hereditary haemorrhagic telangiectasia (Osler-weber-Rendu syndrome): suggested approach for obstetric services. BJOG. 2008;115(9):1108-15 Epub 2008/06/04.

9. Goodman RM, Gresham GE, Roberts PL. Outcome of pregnancy in patients with hereditary hemorrhagic telangiectasia. A retrospective study of 40 patients and 80 matched controls. Fertil Steril. 1967;18(2):272-7.

10. Shovlin CL, Winstock AR, Peters AM, Jackson JE, Hughes JM. Medical complications of pregnancy in hereditary haemorrhagic telangiectasia. Qjm. 1995;88(12):879-87.
11. Wain K, Swanson K, Watson W, Jeavons E, Weaver A, Lindor N. Hereditary hemorrhagic telangiectasia and risks for adverse pregnancy outcomes. Am J Med Genet A. 2012;158A(8):2009-14 Epub 2012/06/20.

12. de Gussem EM, Lausman AY, Beder AJ, Edwards CP, Blanker MH, Terbrugge $K G$, et al. Outcomes of pregnancy in women with hereditary hemorrhagic telangiectasia. Obstet Gynecol. 2014;123(3):514-20 Epub 2014/02/07.

13. Neau JP, Roualdes G, Bataille B, Muckensturm B, Rivasseau T, Gil R, et al. Recurrent intracranial hematomas disclosing Rendu-Osler disease in a pregnant woman. Neurochirurgie. 1988;34(1):64-7 Hematomes intracraniens a repetition revelant une maladie de Rendu-Osler chez une femme enceinte.

14. Sivarani S, Chan YK, Liam CK, Kumar G, Abdullah BJ, Mahadeva S. Education and Imaging. Gastrointestinal: massive intraperitoneal haemorrhage in a young woman with hereditary hemorrhagic telangiectasia. J Gastroenterol Hepatol. 2010;25(9):1587 Epub 2010/08/28.

15. Texier C, Accoceberry M, Grobost V, Chadeyras JB, Gallot D. [Osler-weberRendu disease diagnosed during pregnancy because of an important hemothorax]. Gynecologie, obstetrique, fertilite \& senologie. 2018:46(9):66870. Epub 2018/09/02. Maladie de Rendu-Osler revelee par un hemothorax en cours de grossesse.

16. Md Noh MSF, Abdul Rashid AM, Abdul RE. A massive Hemothorax in a pregnant woman: role of interventional radiology. J bronchol Interventional Pulmonol. 2018;25(3):e30-e2 Epub 2018/06/27.

17. Raiya S, Athavale A, Nair J, Deshmukh H. Hereditary hemorrhagic telangiectasia with hemothorax in pregnancy. Lung India. 2017;34(2):206-7 Epub 2017/04/01.

18. Jakobi P, Weiner Z, Best L, Itskovitz-Eldor J. Hereditary hemorrhagic telangiectasia with pulmonary arteriovenous malformations. Obstet Gynecol. 2001;97(5 Pt 2):813-4.

19. Adegboyega PA, Yuoh G, Adesokan A. Recurrent massive hemothorax in Rendu-Osler-weber syndrome. South Med J. 1996;89(12):1193-6 Epub 1996/ 12/01.

20. Freixinet J, Sanchez-Palacios M, Guerrero D. Rodriguez de Castro F, Gonzalez $D$, Lopez $\mathrm{L}$, et al. pulmonary arteriovenous fistula ruptured to pleural cavity in pregnancy. Scand J Thorac Cardiovasc Surg. 1995;29(1):39-41.

21. Bevelaqua FA, Ordorica SA, Lefleur R, Young B. Osler-weber-Rendu disease. Diagnosis and management of spontaneous hemothorax during pregnancy. N Y State J Med. 1992;92(12):551-2.

22. Laroche CM, Wells F, Shneerson J. Massive hemothorax due to enlarging arteriovenous fistula in pregnancy. Chest. 1992;101(5):1452-4.

23. Gammon RB, Miksa AK, Keller FS. Osler-weber-Rendu disease and pulmonary arteriovenous fistulas. Deterioration and embolotherapy during pregnancy. Chest. 1990;98(6):1522-4.

24. Waring PH, Shaw DB, Brumfield CG. Anesthetic management of a parturient with Osler-weber-Rendu syndrome and rheumatic heart disease. Anesth Analg. 1990;71(1):96-9.

25. Banerjee M, Bandyopadhyay T. A 36-year-old woman with hemiparesis and hemoptysis. Conn Med. 2018;82(7):419-21.

26. Tandon R, Pope-Harman A. An unusual case of Syncope in pregnancy. J Fam Med. 2017:4(1):1-2.

27. Yaniv-Salem SZY, Prabhudesai V, Faughnan ME, Berger H, Geary M. Hereditary hemorrhagic telangiectasia with atypical pulmonary Arteriovenous malformation during advanced pregnancy - a case report. $J$ Clin Med Cas Stud. 2017;2(1):15-8.

28. Wispelaere JF, Trigaux JP, Weynants P, Delos M, Coene BD. Systemic supply to a pulmonary arteriovenous malformation: potential explanation for recurrence. Cardiovasc Intervent Radiol. 1996;19(4):285-7.

29. Worda C, Lang I, Husslein P, Kneussl M. Hereditary hemorrhagic telangiectasia and pregnancy. Obstet Gynecol. 2007;110(2 Pt 2):474-7 Epub 2007/08/02.

30. Swinburne AJ, Fedullo AJ, Gangemi R, Mijangos JA. Hereditary telangiectasia and multiple pulmonary arteriovenous fistulas. Clinical deterioration during pregnancy. Chest. 1986;89(3):459-60.

31. Swietlik E, Doboszynska A. Recurrence of arterio-venous malformations with life-threatening complications in a pregnant woman with hereditary teleangiectasia. J Physiol Pharmacol. 2008;59(Suppl 6):683-8 Epub 2009/02/28.

32. Gillard P, Bataille B, Chauvet-Jauseau MF, Noyelle JM, Vige F, Breheret J. RenduOsler-weber disease and intracranial hemorrhage during pregnancy. A case report. J Gynecol Obstet biol Reprod (Paris). 1996;25(3):294-6 Maladie de Rendu-Oslerweber et hemorragie intra-cranienne pendant la grossesse. A propos d'un cas.

33. Euser AG, Wiegman MJ, Cantineau AE, Zeeman GG. Flash pulmonary edema during cesarean section in a woman with preeclampsia. Pregnancy Hypertension. 2012;2(4):371-3 Epub 2012/10/01. 
34. Berthelot E, Savale L, Guyot A, Rahmoune FC, Bouchachi A, Assayag P. Acute high output heart failure revealing hereditary hemorrhagic telangiectasia in a pregnant woman. Presse Med. 2015;44(3):362-5 Epub 2014/12/24.

35. Lai CF, Dennis A, Graham J. High output cardiac failure in a parturient with hereditary haemorrhagic telangiectasia. Anaesth Intensive Care. 2010;38(2): 381-6 Epub 2010/04/08.

36. Goussous T, Haynes A, Najarian K, Daccarett M, David S. Hereditary hemorrhagic telangiectasia presenting as high output cardiac failure during pregnancy. Cardiol Res Pract. 2009;2009:437237 Epub 2009/12/01.

37. Livneh A, Langevitz P, Morag B, Catania A, Pras M. Functionally reversible hepatic arteriovenous fistulas during pregnancy in patients with hereditary hemorrhagic telangiectasia. South Med J. 1988;81(8):1047-9.

38. Mclnroy B, Zajko AB, Pinna AD. Biliary necrosis due to hepatic involvement with hereditary hemorrhagic telangiectasia. AJR Am J Roentgenol. 1998;170(2):413-5.

39. Bauer T, Britton P, Lomas D, Wight DG, Friend PJ, Alexander GJ. Liver transplantation for hepatic arteriovenous malformation in hereditary haemorrhagic telangiectasia. J Hepatol. 1995;22(5):586-90.

40. Hillert C, Broering DC, Gundlach M, Knoefel WT, Izbicki JR, Rogiers X. Hepatic involvement in hereditary hemorrhagic telangiectasia: an unusual indication for liver transplantation. Liver Transpl. 2001;7(3):266-8.

41. Askim AJ, Thrane AS, Giaever P, Andersen R, Krohn J. Branch retinal artery occlusion as a clinical manifestation of hereditary haemorrhagic telangiectasia (Osler-weber-Rendu syndrome) in pregnancy. Acta Ophthalmol. 2018;96(2):197-9 Epub 2017/10/27.

42. Ashrafi R, Curtis SL. Heart disease and pregnancy. Cardiol Therapy. 2017;6(2): 157-73 Epub 2017/07/07.

43. Rizvi A, Macedo P, Babawale L, Tighe HC, Hughes JMB, Jackson JE, et al. Hemoglobin is a vital determinant of arterial oxygen content in hypoxemic patients with pulmonary Arteriovenous malformations. An Am Thoracic Soc. 2017;14(6):903-11 Epub 2017/03/08.

44. Buscarini E, Leandro G, Conte D, Danesino C, Daina E, Manfredi G, et al. Natural history and outcome of hepatic vascular malformations in a large cohort of patients with hereditary hemorrhagic teleangiectasia. Dig Dis Sci. 2011;56(7):2166-78 Epub 2011/02/04.

45. Buscarini E, Danesino C, Olivieri C, Lupinacci G, De Grazia F, Reduzzi L, et al. Doppler ultrasonographic grading of hepatic vascular malformations in hereditary hemorrhagic telangiectasia -- results of extensive screening. Ultraschall Med. 2004;25(5):348-55.

46. Yoshida K, Takahashi JC, Takenobu Y, Suzuki N, Ogawa A, Miyamoto S. Strokes associated with pregnancy and Puerperium: a Nationwide study by the Japan stroke society. Stroke. 2017;48(2):276-82 Epub 2016/12/29.

47. Lesca G, Olivieri C, Burnichon N, Pagella F, Carette MF, Gilbert-Dussardier B, et al. Genotype-phenotype correlations in hereditary hemorrhagic telangiectasia: data from the French-Italian HHT network. Genet Med. 2007:9(1):14-22

48. Willemse RB, Mager JJ, Westermann CJ, Overtoom TT, Mauser H, Wolbers JG. Bleeding risk of cerebrovascular malformations in hereditary hemorrhagic telangiectasia. J Neurosurg. 2000;92(5):779-84.

49. Kim H, Nelson J, Krings T. terBrugge KG, McCulloch CE, Lawton MT, et al. hemorrhage rates from brain arteriovenous malformation in patients with hereditary hemorrhagic telangiectasia. Stroke. 2015;46(5):1362-4 Epub 2015/04/11.

50. Faughnan ME, Palda VA, Garcia-Tsao G, Geisthoff UW, McDonald J, Proctor $\mathrm{DD}$, et al. International guidelines for the diagnosis and management of hereditary haemorrhagic telangiectasia. J Med Genet. 2011;48(2):73-87 Epub 2009/06/26.

51. Mohr JP, Parides MK, Stapf C, Moquete E, Moy CS, Overbey JR, et al. Medical management with or without interventional therapy for unruptured brain arteriovenous malformations (ARUBA): a multicentre, non-blinded, randomised trial. Lancet. 2014;383(9917):614-21 Epub 2013/11/26.

52. van Beijnum J, van der Worp HB, Buis DR, Al-Shahi Salman R, Kappelle $\sqcup$, Rinkel GJ, et al. Treatment of brain arteriovenous malformations: a systematic review and meta-analysis. JAMA. 2011:306(18):2011-9 Epub 2011/11/10.

53. Mohr JP, Overbey JR, von Kummer R, Stefani MA, Libman R, Stapf C, et al. Functional impairments for outcomes in a randomized trial of unruptured brain AVMs. Neurology. 2017;89(14):1499-506 Epub 2017/09/08.

54. Poisson A, Vasdev A, Brunelle F, Plauchu H, Dupuis-Girod S. Acute paraplegia due to spinal arteriovenous fistula in two patients with hereditary hemorrhagic telangiectasia. Eur J Pediatr. 2009;168(2):135-9.

\section{Publisher's Note}

Springer Nature remains neutral with regard to jurisdictional claims in published maps and institutional affiliations.

Ready to submit your research? Choose BMC and benefit from:

- fast, convenient online submission

- thorough peer review by experienced researchers in your field

- rapid publication on acceptance

- support for research data, including large and complex data types

- gold Open Access which fosters wider collaboration and increased citations

- maximum visibility for your research: over $100 \mathrm{M}$ website views per year

At $\mathrm{BMC}$, research is always in progress.

Learn more biomedcentral.com/submissions 